\title{
JUSTIÇA, HYBRIS E TIRANIA EM ATENAS ARCAICA E CLÁSSICA
}

Profa. Doutoranda Mariana Figueiredo Virgolino ${ }^{1}$

\begin{abstract}
Resumo: Segundo pensadores do século IV a.C, especialmente Platão e Aristóteles, a tirania seria a pior das formas de governo. Todavia, a bibliografia recente sobre as autocracias na Grécia tem entendido que as ligações entre os atenienses e a tirania eram ambíguas. Hybris, por sua vez, é uma noção que foi sofrendo alterações ao longo da história da Grécia Antiga. Se nos poemas homéricos e hesiódicos ela se caracterizava por uma conduta contrária à retidão (dike), uma arrogância marcada por um comportamento no nível do excesso, no período clássico essa palavra estava principalmente relacionada ao ataque à honra (timé) de um cidadão. Pretendemos neste artigo explorar as relações entre tirania e bybris na Atenas dos períodos arcaico (VII-VI séculos a.C) e clássico (V e IV séculos a.C) e compreender as associaçôes entre os tiranos e um comportamento desmedido, hibrístico ao longo das épocas mencionadas.

Palavras-Chave: Tirania; Hybris; Atenas.
\end{abstract}

\section{INTRODUÇÃo}

Apesar da historiografia vivenciar desde a década de 1980 uma revalorização dos estudos sobre política, no que tange ao helenismo a produção ainda se encontra muito focada nos aspectos culturais das cidades gregas. O objetivo do artigo consiste em mapear as representações acerca da noção de hýbris entre os autores do período clássico e relaciona-las ao imaginário ateniense acerca do fenômeno da tirania.

Mesmo que a retórica democrática ateniense tenha tratado a tirania como o seu "Outro" político (MCGLEW, 1993, p.I; RAAFLAUB, 2003, p.59), fica patente -especialmente quando lemos Tucídides- que a pólis em questão não se furtava do exercício de práticas imperialistas sobre as póleis integrantes da Liga de Delos, o que o historiador ático vê como causa da Guerra do Peloponeso (TUCÍDIDES, História da Guerra do Peloponeso, 1.23.6). Com base em tal fato, muitos classicistas chegam a dizer que Atenas se porta como uma pólis 
tirana (polis tyrannos) perante a Liga (CONNOR, 1977, p. 98; BALOT, 2001, p. 127; KALLET, 2003). Em Tucídides é explicitado que os atenienses, em geral, viam seu "império" como algo dado, conseguido não pela força, mas pelo desejo de proteção das cidades que compunham a Liga depois das Guerras Greco-Pérsicas (1.88-118), e que era igualmente natural a necessidade de ampliá-lo e defendê-lo (1.75.3). Assim, ser internamente submetida a um governo tirano ia contra as aspirações de uma pólis que se orgulhava de seu regime democrático, mas que, ao mesmo tempo, buscava explicaçóes e via seu poder sobre outras cidades como uma dominação justa dos mais fracos pelo mais forte (TUCÍDIDES, História da Guerra do Peloponeso, 1.122.3, $1.124 .3,1.73-78)$.

Destarte, a contradição do tratamento da tirania nas fontes escritas oriundas dessa pólis deve ser investigada, de forma que possamos compreender a cultura política ${ }^{2}$ democrática ateniense como algo polissêmico. Nosso objetivo, portanto, é perscrutar essas noçóes comuns que associam o tirano e a bybris nas fontes relacionadas à Atenas.

\section{Homero, Hesíodo e Sólon - A Hybris no Arcaísmo}

Marco inicial da literatura ocidental, a Ilíada começa relatando a fúria de Aquiles sobre o que ele entende ser um ato de desonra perpetrado contra si, uma injustiça: Agamemnon retira-lhe a posse de Briseida (HOMERO, Ilíada, I.356; IX.648). Aristóteles na Retórica (1378b) utiliza justamente o exemplo da indignação do herói para designar o que seria a bybris, conceito geralmente traduzido como insolência, desonra ou desmedida. Segundo o filósofo, essa noção estava atrelada à ideia de desdém, desrespeito (oligoria), sendo um insulto que causa a cólera, raiva. Pelas próprias palavras do estagirita (ARISTÓTELES, Retórica, 1378b):

A insolência (bybris) também é uma forma de desdém (indiferença), na medida em que consiste em dizer e fazer coisas que prejudicam e afligem nossa vítima e que, sobretudo, a humilham. Na insolência não se busca proveito pessoal, e tampouco qualquer acerto - visa-se apenas à própria satisfação. (...) A causa do prazer fruído pelo insolente é

2 Daniel Cefaï e Paul Lichterman definem cultura política como "conjuntos de símbolos e significados ou modos de ação que organizam reivindicações políticas e formação de opiniões por indivíduos e coletividades" (2006, p.392). É através das culturas políticas que os atores sociais referenciam seu comportamento e guiam seus interesses. A conceituação desses sociólogos abre as portas para percebermos o político não como algo internalizado sem questionamento, mas como fruto de negociações e construções cotidianas, com contradições e resistências, plural. 
imaginar-se como sendo muito superior aos outros ao maltratá-los. (...) Por outro lado, a insolência objetiva difamar os outros, ou seja, subtrair a honra que lhes é devida: desonrar é desdenhar. E, de fato, o que não é digno de qualquer consideração, que é desprovido de qualquer importância não atrai respeito algum, seja no bem ou no mal. (grifo nosso)

Muito já se discutiu sobre os possíveis significados da noção de bybris. $\mathrm{O}$ estudo mais famoso é de autoria de N. R. E. Fisher, Hybris: a study in the values of honour and shame in Ancient Greece (1992), que defende que essa noção se caracteriza por "cometer atos de insulto intencional, atos que deliberadamente infligem vergonha e desonra para outros" (FISHER, 1992, p. 148), ou seja, coadunando-se, aparentemente, com a descrição aristotélica deste valor. Todavia, essa definição, tal como é apontado por Douglas L. Cairns, falha ao considerar que o importante é que o bybristés tenha uma ação positiva, de modo a infligir desonra a outrem, deixando de lado os aspectos psicológicos presentes na própria concepção aristotélica: "Aristóteles claramente considera a intenção de desonrar como paralela à intenção de obter o prazer de se sentir ou parecer superior" (CAIRNS, 1996, p. 2, grifos nossos). O aspecto mental da bybris é algo que se manifesta na ação, mas não algo que possa ser definido apenas por ela (CAIRNS, 1994, p. 76-79). O núcleo da bybris residiria, então, em uma grande segurança e exuberância, em ter uma opinião de si mesmo muito elevada (mega phronei), acima da sua condição de mortal. Daí bybris ser geralmente um termo traduzido como "desmedida". A questão da honra, na Grécia Antiga, deve ser encarada tal como um "jogo de soma zero": ela envolve um elemento de comparação e o excesso de autoafirmação e arrogância de si tem inevitável impacto sobre a honra alheia (CAIRNS, 1996, p. 1-32).

Um estado de espírito que valorize demais a própria honra é elemento decisivo para a caracterização da bybris, ideia que também envolve orgulho, soberba e vaidade. Consideraremos no presente artigo a concepção de bybris aristotélica (Retórica, 1378b23-8; 1374a13-15) interpretada por Cairns (1996, p. 16, nota 68):

Hybris certamente se refere a atos concretos, incluindo a falha em reconhecer a honra dos deuses, mas isto também é associado com 'pensamentos ímpios', 'pensar excessivamente para um mortal', 'desprezar a presente fortuna de alguém,' 'pensamentos excessivamente orgulhosos' e 'ofender os deuses com a audácia de vangloriar-se em excesso'; se os resultados desastrosos da bybris dão razão para evitar pensamentos excessivos, pensamentos imortais, assim 'pesar mais do que pensamentos mortais' deve ser uma forma de bybris. 
Segundo H.G. Robertson (1955, p.81-83), bybris e ate (erro, ruína, loucura, castigo) são ideias que se justapõem em Homero. Enquanto a primeira se refere à desmedida e à insolência, a ter um prazer na desonra do outro, a segunda trata das consequências da cegueira e do desvario heroico, envolvendo ainda a ideia de que a ação em erro será alvo de punição. Essa justaposição alegada por Robertson fica bastante clara na Odisseia, quando Odisseu relata que seus homens comeram o gado do Sol. Por desrespeitarem a propriedade do Sol, incorreram em bybris ${ }^{3}$. Odisseu, por dormir e não vigiar seus companheiros, percebe que será punido por seu erro (HOMERO, Odisseia, XII, 370-373):

Gemendo, assim, gritei aos deuses imortais:

'Zeus pai, e vós outros deuses que sois para sempre!

Para a minha ruína me adormecestes com sono desapiedado ficando os companheiros a cometer um ato tremendo. (grifo nosso)

Hipérion (o Sol) urge Zeus a garantir a justiça contra a bybris dos companheiros de Odisseu (XII, 377-383):

Zeus pai, e vós outros deuses que sois para sempre!

Vingai-vos dos companheiros de Odisseus, filho de Laertes, que na sua insolência me mataram o gado, no qual eu sempre me deleitava quando subia para o céu repleto de astros e quando de novo à terra do céu eu regressava.

Se deles não receber expiação condigna, irei para o Hades e lá brilharei para os mortos. (grifo nosso)

A bybris dos hetairoi ${ }^{4}$ coloca em risco todo o mundo humano: o Sol ameaça não brilhar mais para os que têm vida. Odysseus sofre as consequências junto aos bybristai: Zeus fulmina o barco onde eles estão e todos perecem, exceto o herói (HOMERO, Odisseia, XII, 385-388):

Sol, continua a brilhar para os imortais e para

os homens mortais na terra dadora de cereais.

Em breve, com o raio fulgurante, a nau veloz

despedaçarei no meio do mar cor de vinho. (grifo nosso)

\footnotetext{
3 Euríloco diz: "Mas se o deus contra nós se encolerizar por causa da vacas/ de chifres direitos e a nau quiser destruir, e se tal consentirem/ os outros deuses, por mim prefiro morrer de um trago no mar/ do que definhar lentamente numa ilha deserta" (grifos nossos). Ou seja, ele sabe que está agredindo a propriedade do deus, mas coloca sua fome acima do respeito devido aos deuses. HOMERO, Odisseia, XII, 348-351.
}

4 Hetairoi no período arcaico significava os companheiros de armas, e no período clássico pessoas pertencentes a um mesmo grupo que comungava de ideais políticos semelhantes, em geral oligarcas. 
Vemos que hybris e ate são noções contrárias à justiça divina dada por Zeus. O excesso e o erro levam à uma quebra da boa ordem (eunomia), colocam em risco a coletividade e a harmonia tanto entre os homens quanto desses com os deuses. A bybris de Agamemnon contra a honra (timé) de Aquiles faz com que várias helenos morram em campo de batalha (HOMERO, Ilíada, I, 1-5; 488-530), ameaçando a vitória grega. Esse último herói também é acusado de hybris em diversos momentos do poema, mais notadamente por Apolo e Zeus quando viola o cadáver de Heitor (HOMERO, Ilíada, XXIV, 55-187). Shirley D. Sullivan (1995, p. 177-180) afirma que na época arcaica as noções de justiça possuía aspectos legais, morais e políticos, operando tanto no nível cósmico quanto no humano. Na literatura arcaica "justiça" é utilizado como "aquilo que é correto", o correto é a justa medida, dar a cada um o seu quinhão de direito (JAEGER, 2013, p. 97; 100-105). Não se trata, portanto, de uma justiça equitativa, mas distributiva e meritocrática. Em Homero, afirma Sullivan (1995, p. 177-182), dike e themis são noções semelhantes. Themis é tida como uma ideia mais antiga, estando personificada nos poemas homéricos numa deidade, Themis. O termo significaria "aquilo que foi posto", que é apropriado, "julgamentos", "decisões", "costumes" e estaria associado à aristocracia, a uma justiça divinizada. Com o tempo, a utilização do termo vai sendo restringida às relações entre deuses e homens ${ }^{5}$.

Já dike seria uma "direção", um “comportamento, ação" (SULLIVAN,1995, p. 176-177). Legalmente, caracterizaria o conteúdo de uma decisão, uma sentença, um processo, um princípio regente de processos jurídicos, uma conduta de acordo com a lei, correta, o oposto de hybris. Zeus, como detentor da themis, ou seja, da capacidade de colocar os costumes, é o responsável pela aplicação da dyke (ações corretas) contra os hybristai (os que erram em sua ideia de honra), sendo patrono do kosmos, a ordem. Em Homero a bybris é associada ao comportamento insolente, ruim, enquanto a dike é a ação justa, o "dar a cada um aquilo que lhe cabe" ${ }^{\prime}$. Os physikoi pré-socráticos também aludem à justiça num sentido amplo, um princípio regulador da ordem cósmica (BRYANT, 1996, p. 121).

5 Para mais informações acerca das diferenças entre Themis e Diké, ver THEML, 1998, p. 33.

6 Por exemplo, na Ilíada, Odisseu sugere que Aquiles atenda o festim na tenda de Agamemnon a fim de não perder sua parte no butim (HOMERO, Ilíada, XIX, 172-180). Ou quando consideramos a ação dos pretendentes de Penélope, que dilapidam o patrimônio do palácio, comportando-se, portanto, de maneira incorreta, injusta, sendo bybristai, e depois encontram seu castigo morrendo pelas mãos de Odisseu, Telêmaco e Filécio. Como afirma Penélope: "Foi algum dos imortais que matou os arrogantes pretendentes, /encolerizado por causa da sua insolência dolorosa e más ações, /Não respeitaram homem algum na terra, vil ou bem-nascido,/ que com eles convivesse. Deu-lhes o desvario de uma morte vergonhosa" (HOMERO, Odisseia, XXIII, 63-67, grifo nosso). 
Destarte, insolência/desmedida (bybris), erro/ruína (ate), honra (timé) e costume/justiça (themis/dike) são noções ligadas entre si, que se opõem e se complementam. É a bybris que dá início às ações cujo enredo forma os poemas homéricos, é através dela que a função educativa dos cantos épicos se cumpre, pois o herói erra e sofre por sua bybris e seu pathos (sofrimento) é o "espelho" para que o público siga o caminho da retidão.

Também na poesia hesiódica -especialmente em Os Trabalhos e os Diasestá presente a associação entre bybris (insolência), timé (honra) e dike (justiça). Essa última mantém seus aspectos morais, legais e políticos. Todavia, o termo dike possui uma significação mais ampla para o poeta beócio: ainda há o sentido de "julgamento", que deve ser correto, de "processo", mas também de "punição" (v.710-713). A justiça hesiódica implica "uma consciência do que é correto e o reconhecimento das reivindicações alheias" (SULLIVAN, 1995, p. 184). Vemos entre Homero e Hesíodo um quádruplo deslocamento: "do herói para o homem comum; da guerra para a ágora, isto é, para o cotidiano; da glória para a bybris e, por fim, a separação entre deuses e homens" (MANTOVANELI, 2011, p. 37). Segundo Jean-Pierre Vernant (2009, p. 79), as relações sociais na época de Hesíodo estariam "marcadas pela violência, pela astúcia, pela arbitrariedade e pela injustiça”. Ou seja: o helenista francês corrobora a visão de uma crise agrária e social ${ }^{7}$ que coloca em xeque a justiça nas relações entre aristocratas e camponeses na gênese da pólis ${ }^{8}$.

Em O Trabalho e os Dias, Hesíodo adverte que Perses, seu irmão, ao cobiçar seu patrimônio e usar dos subornos para obter vantagens incorre em uma luta ruim, ao contrário da boa luta (agathé éris), que estimula o trabalho e a prosperidade, conforme alude o trecho a seguir (v. 20-34):

Esta desperta ao trabalho até o indolente/ pois anseia por trabalho ao olhar para o outro,/ rico, que se apressa a arar, e a plantar/ e bem dispor a casa. E vizinho emula vizinho/ que corre atrás da riqueza. Esta é a boa luta para os mortais./ $O$ oleiro provoca o oleiro e o carpinteiro ao carpinteiro, /mendigo se mede ao mendigo, aedo ao aedo. /Oh, Perses! Guarda isso em teu ânimo:/ que a Luta que se alega com o mal não te desvie o ânimo do trabalho (...)/ Ao tempo certo, a terra traz o alimento de Deméter./ Fartando-te disso, poderias entrar em arengas e brigas em vista dos bens alheios. (grifos nossos)

\footnotetext{
7 Dentre os autores que corroboram a ideia de uma crise agrária no início do Período Arcaico, ver: TRALBUSI, 2004; WILL, 1955; MOSSÉ, 1989; FINLEY, 1997.

8 Há uma corrente que enxerga o conflito entre Perses e Hesíodo como uma querela familiar, minimizando os 'efeitos' de uma crise agrária, em especial, na leitura da obra hesiódica: "Nós teríamos com o poema hesiódico a expressão de uma situação ocasional de dificuldade familiar, não a descrição de uma crise estrutural das comunidades gregas do VII século a. C." (DUPLOY, 2010, p. 277)
} 
Como é sabido, o poema em tela trata da disputa entre o poeta e seu irmão pela herança do pai de ambos. Apesar de já terem acordado sobre a partilha, tendo Perses subornado os "reis comedores de presentes" para obter o maior quinhão, ele dilapida seu patrimônio e passa a reclamar para si a parte que cabia a Hesíodo por direito, incorrendo em hybris, agindo e pensando de forma contrária ao que é justo, conforme destaca o seguinte trecho (v. 213218):

Oh, Perses, ouça a Justiça e não dê força à desmedida (bybris)./ A desmedida é má para o pobre mortal. Nem mesmo o nobre/ a pode aguentar facilmente. É esmagado por ela/ quando cede à Ilusão. Mas há outro caminho a seguir/ que é melhor: o das coisas justas. Justiça vence a desmedida,/ revelando-se ao fim. E o tolo aprende sofrendo. (grifos nossos)

Em Hesíodo, para haver justiça (dike) é preciso também existir aidós (vergonha, respeito, consideração) para com aquilo que cabe a outro e a reprovação àquilo que não é correto, justo (nemesis). Todas essas noções são contrárias à arrogância que rebaixa e ofende o próximo (SULLIVAN, 1995, p.184).

Nem mesmo os nobres escapam à crítica de Hesíodo, uma vez que ao ferirem a justiça também contrariam os desígnios de Zeus, que "com justiça endireita as sentenças” (Os Trabalhos e os Dias, v.9). Trata-se, portanto, de uma justiça que caracteriza-se pela perfeição, pois é divina. No plano humano ela está vinculada à palavra aristocrática (VERNANT, 2009, p.57; DETIENNE, 2013, p.65). A justiça humana é imperfeita, pois os homens como Perses e os "rei comedores de presentes" incorrem em desrespeito à justa medida (sophrosyne) para obterem vantagens pessoais. O correto, assim, é que cada um tenha o fruto do seu trabalho, que nasce como castigo divino, mas que se torna parte da areté (virtudelexcelência) e da glória humanas9. Vemos, portanto, claramente acima que a bybris (desmedida, na tradução) é, para

\footnotetext{
9 Essa afirmação é explicitada pelo mito de Prometeu. À raça de ferro "os deuses darão duras angústias". Todavia, aos que trabalham e guardam as "retas trocas", recebem as recompensas divinas: "em festa repartem os frutos do trabalho. A estes a terra dá muito alimento" (HESÍODO, Os Trabalhos e os Dias, v. 47-235). A associação areté/érgon (virtude e trabalho) também está clara na famosa "passagem dos caminhos": “(...) mui pronto o vício conquista multidóes, é muito fácil: seu caminho é plano e está logo ali. Mas perante a virtude suor ordenaram os deuses imortais. É longa e inclinada a subida até ele, espinhosa no início, mas quando se chega ao topo mais fácil se torna, ainda que seja difícil", (v. 286-292). Werner Jaeger afirma que em Hesíodo a areté do camponês é a justiça e o trabalho (2013, p.101-102).
} 
Hesíodo, a oposição à dike, Justiça. A glória $(k y d o s)^{10}$ também está vinculada ao trabalho (HESÍODO, Os Trabalhos e Dias, v. 311-313):

Trabalho não é vergonha. Vergonha é não trabalhar/ se trabalhares, logo te inveja o preguiçoso/ porque enriqueces. Sucesso e glória acompanham a riqueza.

No fim do poema Hesíodo declara que o homem feliz trabalha e não possui culpa perante os imortais, pois observa os auspícios e evita os exageros (HESÍODO, Os Trabalhos e os Dias, v. 826-828). Ele aceita que o trabalho é a tarefa dada por Zeus à humanidade diante dos erros de Prometeu ${ }^{11}$, isso é o que lhe cabe em vida. A justa medida (sophrosyne) em Trabalhos e Dias seria, destarte, análoga à dike e à boa luta (LAFER, 1996, p.58): ter aquilo que lhe cabe, conseguido pelo trabalho, que se torna abençoado pelos deuses. Nas palavras do próprio poeta (HESÍODO, Os Trabalhos e os Dias, v.306): "que te empenhes em articular obras certas (soi d' erga phil' esto metria kosmein)". Hesíodo traz em sua poesia, portanto, o germe do pensamento político que fará da questão da Justiça e da hybris cerne da política e do direito na pólis arcaica ${ }^{12}$. Ao analisarmos os textos referentes ao período notamos que essa violência pessoal pode afetar a coletividade, causar ruína (ate), tal como ocorreu os gregos na Ilíada, que perdiam as batalhas contra os troianos enquanto Aquiles não voltou às armas até a morte de Pátroclo. A discussão da bybris ganha o espaço público e o interesse dos legisladores, pois era importante para toda a comunidade. A pólis -ao zelar pela justa medida (sophrosyne) e pela justiça (dike)-deve combater a hybris entre seus componentes.

As primeiras leis contra bybris datam do século VI a.C. A poesia de Sólon demonstra que as questóes da justiça, da boa medida e a bybris continuarão a ser tratadas em versos. $\mathrm{O}$ estadista atenta sobre a desmedida: os cidadãos colocariam em risco a eunomia (boa ordem) da cidade com seus desejos de enriquecerem injustamente. Quando agem movidos pela bybris, a cidade recai em ruína (ate), pois Zeus, responsável pela justiça, traz punições severas aos que cometem "ações injustas" (FR 4W):

10 Marcel Detienne explica que kydos é a glória “que ilumina o vencedor; é uma espécie de graça instantânea". Vem dos deuses, enquanto kléos é a glória da façanha, decorrente de uma fama que se constrói ao passar das gerações (2013, p.21).

11 Ver as famosas análises de Vernant sobre o mito prometeico em VERNANT, 1983 e VERNANT, 1999.

12 Louis Gernet caracteriza o século VIII a.C como um Estado de Pré-Direito. A justiça empreendida pelos aristocratas não se configura em Direito per si por não haver tribunais autônomos (GERNET, 2001, p.81). Contra essa ideia, temos: FISHER, 1990. 
Mas os próprios cidadãos, com seus desvarios, / querem destruir a grande pólis, persuadidos por riquezas, / e injusto é o noos (propósito) dos chefes do povo, aos quais está reservado/ sofrer muitas aflições por sua grande bybris (insolência)/ pois eles não são capazes de conter seu koros (saciedade)/ nem controlar, na tranquilidade do banquete, seus prazeres. / (...)/ Enriquecem, persuadidos por ações injustas./ (...)/ Não poupando os bens sagrados nem, de modo algum, os públicos,/ roubam com avidez, cada um por seu lado,/ nem guardam os veneráveis fundamentos da dike (justiça),/ que, em silêncio, conhece o passado e o presente,/ e, com o tempo, certamente vem punir./ Essa ferida inevitável já atinge toda a pólis,/ e rapidamente conduz à perversa escravidão,/ que desperta a stasis (instabilidade) e a guerra adormecida, / a qual póe termo à agradável juventude de muitos; / de fato, por causa dos inimigos, rapidamente, a encantadora cidade/ é destruída em conspirações que prejudicam os amigos. (grifos nossos)

Resta, portanto, claro que a stásis, para Sólon, é fruto da bybris do corpo político -tanto da aristocracia quanto do demos- por almejar mais que aquilo que lhe é de direito, quebrando a igualdade geométrica e indo contra a vontade divina. (FR 36W).

Essas coisas, por meio do poder,/ tendo unido, ao mesmo tempo, a força e a dike (justiça),/ eu realizei e fui até o fim, como prometi; / leis tanto para o homem comum quanto para o nobre,/ adaptando uma sentença justa para cada um,/ eu redigi. (grifo nosso)

Ele próprio afirma que poderia ter buscado a tirania para si (FR 32W); Todavia, seu repúdio por esse regime o leva a legislar de modo a garantir sentenças justas e punições àqueles que atentassem contra a politeia ateniense (ARISTÓTELES, Constituição de Atenas, VIII.4).

Mas, se outro tivesse como eu, tomado o aguilhão,/ um homem perverso e ambicioso,/ não teria contido o povo; pois se eu quisesse/ as coisas que então agradavam aos meus adversários, / ou as coisas que contra eles outros planejavam,/ essa pólis já estaria privada de muitos homens./ Por isso, prestando socorro por todos os lados,/ como um lobo, eu ia e vinha entre muitos cães." (SÓLON, FR 36 W, grifo nosso)

Muitos classicistas tentaram remontar os significados da Graphe Hybreos mencionada por Demóstenes em Contra Mídias (47) ${ }^{13}$. De acordo com Elizabeth Irwin (2005, p. 190-191), tanto em Homero quanto na poesia 
de Sólon a eunomia se relaciona com a dike e se opõe à bybris. Assim, a noção de eunomia soloniana estaria concatenada com as hórai da Teogonia: em ambos Justiça (Dike), Paz (Eirené) e a Boa Ordem (Eunomia) são fundamentais para a harmonia da comunidade.

Estas coisas meu coração me ordena ensinar aos atenienses: / que a disnomia (desordem) causa males inumeráveis à pólis,/ mas a eunomia (boa ordem) mostra tudo bem ordenado e bem proporcionado,/ e, muitas vezes, agrilhoa os injustos,/ abranda a violência, faz cessar o koros, enfraquece a bybris (insolência)/ seca as flores nascidas da desgraça, / corrige os decretos tortuosos, suaviza as ações arrogantes,/ põe fim aos atos da dissensão, / e faz cessar o ódio da terrível rivalidade, e, graças a ela,/ tudo entre os homens é bem proporcionado e sábio. (SÓLON, FR 4W, grifos nossos)

Alcançamos aqui o ponto em que queríamos chegar depois dessa longa apresentação de alguns aspectos da bybris na poesia arcaica: poderíamos caracterizar o tirano como um bybristes, ou seja, uma pessoa que pensa tão bem de si a ponto de ferir a honra de outros na cultura política ateniense dos períodos arcaico e clássico? Para respondermos tal questionamento nos basearemos nas visões de pensadores dos séculos V e IV a.C, como Platão, Isócrates e Aristóteles, assim como demonstramos que na poesia soloniana o tirano é descrito como alguém cobiçoso de riquezas, violento e perverso, que deseja um poder que não deveria estar ao seu alcance, pois fere a porção da honra (time) que cabe a cada um:

(Diz) se eu poupei a terra

pátria, e também não me apoderei da tirania e da implacável violência, maculando e desonrando a minha reputação, de nada me envergonho: pois assim parece melhor que eu vença todos os homens. (FR 32W, grifo nosso)

\section{Tirania e Atenas}

Como dito, a análise da poesia de Sólon (FR 9W, FR 32W), bem como a de Arquíloco (FR 19W) permite perceber que já no Período Arcaico a tirania não gozava de boa fama entre os letrados em Atenas. Cabe salientar que as medidas tomadas por Sólon enquanto legislador não dão conta da stasis em que se encontra a pólis. Legisladores e tiranos surgem no contexto de crise social, agrária (econômica) e política (LEFÈVRE, 2013, p. 118) no qual as poleis se veem mergulhadas no princípio do período arcaico. Os tiranos 
compunham um fenômeno ambíguo e a origem ateniense da grande parte das fontes escritas que chegou até nós construiu no imaginário ocidental a ideia negativa desses atores políticos, geralmente retratados como déspotas sanguinários (LEFÈVRE, 2013, p. 119). Essa ambiguidade resta patente quando encontramos nomes como Periandros de Corinto ${ }^{14}$ e Cleóbulos de Lindos nomeados como alguns dos Sete Sábios (oi hepta sophoi) da Grécia Antiga (DIÓGENES LAÉRCIO, Vidas e Doutrinas dos Filósofos Ilustres, I.4; I.7). Esses filhos da aristocracia chegavam ao poder pelo exercício de magistraturas e sucessos militares e, sendo figuras dotadas de carisma e de visualização social, farão uso dos atritos entre a aristocracia e o demos para exercer o controle político de suas póleis.

Diz José Antonio Dabdab Tralbusi (2001, p. 50-65) que a emergência do tirano como "homem providencial", ou seja, mobilizador e catalisador de mudanças sociais, coaduna-se à fragilidade política das pólis. A necessidade de coesão interna para proteger-se dos perigos e tentativas de dominação externos, como por exemplo os persas, levam os cidadãos a fazerem concessões de seus direitos políticos a essas grandes figuras, catalisadoras dos descontentamentos do demos, inicialmente, através de medidas "populistas". Cabe ressaltar que as tiranias na Grécia Antiga não ocorreram apenas no período arcaico, sendo os casos sicilianos famosos exemplos de que esse fenômeno ocorrera em pleno período clássico, convivendo com outros tipos de regimes políticos. Édouard Will (1955) também apresenta uma visão diferente, na qual o tirano está vinculado mais às tensões e disputas de poder dentro da própria aristocracia que uma resposta a demandas populares, que hoje é a mais aceita pelos classicistas dedicados ao estudo do fenômeno tirânico (ANDERSON, 2005; LEWIS, 2009).

As visões sobre a tirania nas fontes escritas da Antiguidade que sobreviveram até nós, segundo os trabalhos recentes sobre o tema, são de caráter ambíguo, assim como é a definição do próprio fenômeno, conforme mencionamos anteriormente. Sian Lewis (2009, p. 2-14) atenta que o sentido original da palavra tyrannos não necessariamente estava atribuído de conotação ruim, significando alguém que, não sendo um monarca, tomava para si o poder em caráter pessoal e absoluto. A helenista ressalta a dificuldade em caracterizar os governos autocráticos da Grécia Antiga, uma vez que nem mesmo os helenos utilizavam o termo de forma consistente ${ }^{15}$.

14 Tratamos sobre as ações de Periandros em dois trabalhos anteriores (VIRGOLINO, $2014 \mathrm{e}$ VIRGOLINO, 2016).

15 Sian Lewis dá a seguinte definição: tiranos eram governantes unos, seja como indivíduos ou famílias, com poder direto e pessoal sobre o Estado, não restringido por instituições políticas. Eles investiam na monumentalização de suas cidades e tentavam estabelecer dinastias hereditárias (LEWIS, 2009, p.2-14). 
A partir do século $\mathrm{V}$, a designação "tirano" vai amealhando carga cada vez mais negativa. Conforme concordam vários autores ${ }^{16}$, é com o advento das guerras com os persas e, principalmente, com a influência que Atenas vai adquirindo junto às demais poleis que o tirano vai passar a ser descrito de forma cada vez mais pejorativa, e a influência da literatura ateniense construiu a negatividade da palavra tirania desde então. Análises ${ }^{17}$ sobre o papel ocupado por reis e tiranos na obra de Heródoto, por exemplo, mostram que o historiador não fazia distinções claras entre monarquia e tirania, e que também não há um juízo de valor majoritariamente negativo sobre essa última forma de governo. Quando relata os concursos engendrados por Clístenes, tirano de Sicione, para encontrar um marido para sua filha, Agariste, Heródoto afirma que aristoi de diversas partes da Hélade não hesitaram em tomar parte nas disputas a fim de entrarem para o círculo familiar do tirano (HERÓDOTO, Histórias, VI.126-130). O próprio Aristóteles (Constituição de Atenas, XVI.9-10) fala que a administração de Psistratos dos negócios de Atenas fora amena:

Com efeito, a maioria dos notáveis e dos populares o apoiava, pois ele conciliava uns por meio do convívio, e outros pela assistência prestada a seus interesses privados, estando naturalmente bem disposto para ambos. (grifo nosso)

Também Sófocles não faz de Édipo uma figura de caráter mau em Édipo Rei (tyrannos, no original) ou Édipo em Colono, peças concebidas na segunda metade do século V a.C. Todavia, Platão (República, 566d-67d) e Aristóteles (Política, 1287b-1288a) descrevem a tirania como a pior e mais degenerada forma de governo.

Com o fim das Guerras Greco-Pérsicas e sua necessidade de reforçar a identidade democrática, bem como a relevância política e econômica que Atenas vai conquistando na Hélade, a cultura política democrática ateniense faz do persa o "Outro" a ser combatido, e coloca a tirania como o "Outro" ideológico, o que segundo Lewis (2009, p. 37-46) é visível nas Histórias. O que encontramos nos discursos, porém, muitas vezes não se confirmava na prática: Atenas, apesar de toda a exortação da democracia contida no discurso fúnebre declamado por Péricles (TUCÍDIDES, História da Guerra do Peloponeso, 2.35-46), era vista como uma pólis que exercia tirania sobre as demais cidades da Liga de Delos, bem como apoiou governos tirânicos quando assim the pareceu melhor.

16 Por exemplo: MCGLEW, 1993, p. 204; PARKER, 1998, p. 158-166; MUNN, 2006, p. 18 ; DEWALD, 2003, p. 26.

17 Ver: CONDILO, 2010; HARTOG, 1999; DEWALD, 2003, entre outros. 
Como afirmado anteriormente, buscamos aqui questionar se na cultura e no pensamento político predominante em Atenas o tirano pode ser configurado como um bybristes um dos objetivos do presente trabalho. Trataremos a seguir acerca da cultura política filosófica ateniense. Primeiramente consideraremos a visão platônica sobre a tirania; a seguir abordaremos as ideias de Isócrates e, por fim, retornaremos ao ponto inicial da presente discussão, qual seja: a visão aristotélica sobre bybris e tirania.

\section{Platão: Justiça, Hybris e a Psyché do Tirano}

No livro IV da República, Platão trata a justiça como fundamento universal para a construção da cidade ideal (433a-b). Ela deve ser realizada tanto no plano individual quanto no coletivo, estando restringida à natureza de cada um:

Sócrates: Agora, pois, vê se tenho razão. O princípio que estabelecemos de início, ao fundarmos a cidade, e que devia ser sempre observado, esse princípio ou uma das suas formas é, creio, a justiça. Nós estabelecemos, e repetimo-lo muitas vezes, que cada um deve ocuparse na cidade apenas de uma tarefa, aquela para a qual é mais apto por natureza.

Glauco: Foi o que estabelecemos.

Sócrates: Mais ainda: que a justiça consiste em fazer o seu próprio trabalho e não interferir no dos outros. Muitos disseram isso e nós próprios o dissemos muitas vezes.

Glauco: Efetivamente, dissemos.

Sócrates: Assim, esse princípio que ordena a cada um que desempenhe a sua função própria poderia ser, de certo modo, a justiça. Sabes o que me leva a pensar assim? (grifos nossos).

As capacidades pessoais estão intrinsecamente ligadas à dike platônica. Ultrapassar sua devida esfera de ação é interferir na de outrem, desequilibrar o bom funcionamento da pólis, sua harmonia natural. Assim como a justiça organiza a cidade, ela também deve estruturar a alma (psyché) humana, que está dividida em 3 partes (PLATÃO, República, 436a): lógica/racional (philomathés/logistikon), localizada na cabeça (PLATÃO, Timeu,44d), imortal, ligada ao conhecimento e à busca da verdade, característica -na visão platônicado temperamento filosófico ateniense (PLATÃO, República, 435a-e; Timeu, $73 \mathrm{~b}-\mathrm{e}$ ). Essa seria a menor parte da psyché, mas a que deve estar no comando das demais para que haja justiça (PLATÃO, República, 441d-442d); a porção irascível/colérica (thymoeides), comandada pelo coração, é a responsável pela 
força de vontade e a coragem, sendo típica dos trácios e citas (PLATÃO, República, 435e-439e; Timeu, 69e-70d). Quando alinhada com a razão, a alma é forte e boa. Todavia, se cede à última parte, concupiscente/desejante (epithymetikon), corresponde ao baixo ventre (PLATÃO, República, 439de; Timeu, 77b-c), a alma se torna sujeita aos prazeres e apetites carnais. A última cota da alma se opõe à primeira e está relacionada a povos "amantes das riquezas" (philochrematon) como os egípcios e fenícios (436a), aos requintes e luxos afro-asiáticos, contrários ao comedimento e frugalidade que Platão atribui aos atenienses. $\mathrm{Na}$ alma governada pelos prazeres, as virtudes cardeais ${ }^{18}$ não podem coexistir harmoniosamente com os apetites que a desequilibram e, destarte, a felicidade (eudaimonia) não é realizada (PLATÃO, Fedro, $246 a-254 \mathrm{e})^{19}$. A porção concupiscente tenta governar as demais, mesmo que isso seja prejudicial ao ser como um todo (BALOT, 2001, p. 10). O corpo (soma), nessa visão, é tumba (sema) que aprisiona a alma (psyché) (PLATÃO, Górgias, 493a; Fédon, 82c-83b). A paideia grega clássica tinha como objetivo justamente que os jovens se tornassem capazes de controlar os apetites e desejos do corpo (FOUCALT, 1998, p. 217).

No pensamento platônico, o tirano deixa-se governar por seus apetites, sua psyché está submetida à porção epithymetikon. Sedento de luxo, dinheiro e prazeres, ele não apenas causa sua própria ruína, mas a de toda a cidade. Não sendo capaz de controlar seus sentimentos e desejos pela razão, ele tampouco poderá conduzir a cidade a uma existência satisfatória. O filósofo seria o governante ideal para Platão, pois sua psyché está sob o comando da parte logistikon (PLATÃO, República, 473c-e). Uma cidade governada por um tirano está no espectro oposto ao bom governo (PLATÃO, República, 420c).

Hybris e sophrosyne são conceitos contrários em Platão. A alma dominada pelos prazeres não é virtuosa, não almeja a justiça, mas a satisfação de suas vontades, como mostra o seguinte trecho Fedro (237e-238a):

18 Platão descreve como virtudes que devem constar tanto na pólis quanto no homem: prudência/ sabedoria (phronesis), coragem/fortaleza (andreia), temperança (sophrosyne) e justiça (dikayosine). Ver: PLATÃO, República, 426-435. A piedade (bosiotes) é incluída no rol de virtudes descritas no Protágoras (330b).

19 O tema é melhor exemplificado na alegoria do cocheiro presente em Fedro: A psyché é comparada a uma carruagem puxada por dois cavalos. $\mathrm{O}$ cocheiro seria a porção racional (logistikon). $\mathrm{O}$ bom cavalo, branco e imortal, é a parte irascível (thymoeides), enquanto o cavalo ruim (mortal, de cor preta) representa a fração concupiscente (epithymetikon). Assim como a carruagem deve ser comandada pelo cocheiro para bem chegar a seu destino, a psyché tem de estar sob o domínio da razão para que o bem-estar e a felicidade (eudaimonia) possam ser alcançados. Uma mente controlada pela razão é propensa à coragem (andreia) e à excelência (areté), o que resulta em uma existência satisfatória (eudaimonia). 
(...) em cada um de nós existem dois princípios, de forma e de conduta, que seguimos para onde eles nos conduzem: um, inato, é o desejo do prazer, outro, adquirido, que aspira sempre ao melhor ....) quando sai vencedora a forma orientada pela razão, essa forma chama-se temperança (sophrosyne); quando é o desejo que, destituído de razão, nos arrasta para os prazeres e nos conduz a nosso belo talante, essa forma chama-se gula (bybris). (grifos nossos)

A tirania é descrita na República de forma claramente negativa (562a). O homem tirânico é um desvio do homem democrático (544a-e), governado pelas paixões e o mais infeliz dos seres, pois torna-se escravo de seus apetites, passa a ter medo do povo e apela para a violência para manter seu poder:

Verdadeiramente, a tirania não se originou de nenhum outro governo senão da democracia, seguindo-se ai liberdade extrema, penso eu, uma extrema e cruel servidão. (564a)

É necessário, desse modo, que o tirano os elimine, se quiser continuar a ser o chefe, e que acabe por não deixar, tanto entre os seus amigos como entre os inimigos, nenhum homem de algum valor. Com olhar arguto, deve distinguir os que têm coragem, grandeza de alma, prudência, riquezas, e a sua felicidade é tanta que se vê forçado, quer queira, quer não, a declarar guerra a todos e a preparar-lhes armadilhas, até que consiga depurar o Estado. (567b-c, grifo nosso)

Pelo que dizes, o tirano é um parricida e um triste apoio dos idosos. Então, ao que me parece, chegamos ao que se costuma chamar de tirania: o povo, de acordo com o ditado, evitando a fumaça da submissão a homens livres, caiu no fogo do despotismo dos escravos e, em troca de uma liberdade excessiva e inoportuna, vestiu a farda mais dura e mais amarga das servidóes. (569b-c, grifo nosso)

$\mathrm{O}$ excesso de liberdade da democracia causa anarquia. Esse mau uso da liberdade, por sua vez, vê surgir a figura do tirano para reorganizar a cidade. Mas, sendo um falso regime, a tirania traz um falsa justiça. O excesso de liberdade porta consigo um excesso de escravidão (PLATÃO, República, 564a). A Callipolis platônica é aristocrática, pois homens bemnascidos teriam a psyché governada pela porção racional. O tirano, assim, é bybristés, o mais injusto e infeliz dos homens (PLATÃO, República, 545a, 578 b-c). Suas condutas são contrárias à dyké pois ele é controlado pela porção irracional da psyché (577-578a) e concentra em si as riquezas e o exercício do poder, negando aos aristoi sua fatia naquilo que lhes cabe na pólis: a posição privilegiada na resolução das questões da cidade. Sua alma é escravizada por 
seus prazeres, sujeita à injustiça (PLATÃO, Fédon, 82c-83a) e as pessoas na cidade governada pelo tirano também estão cativas (PLATÃO, República, $577 c-d)$.

\section{Isócrates: Educação e Participação da Aristocracia na Política}

Assim como Platão, Isócrates também concebe a alma como politeia (ISÓCRATES, Antídose, 181; Aeropagítico, 14), de forma que o comportamento individual é analisado por ambos os pensadores em termos políticos (MORGAN, 2003, p. 211). Como os membros mais bem-educados da cidade, os aristoi possuiriam maior autocontrole e destarte seriam os mais indicados para desempenhar as funções administrativas da pólis. Isso fica explícito pela leitura do Antídose, texto no qual o retórico expõe que, como professor, sua maior contribuição à cidade de Atenas fora na formação de cidadãos aptos a serem líderes na cidade através de uma educação retórica, calcada na verdade comum (ISÓCRATES, Antidose, 81-84):

(...) é deveras necessário que aqueles que empreendem o trabalho de criar tais discursos sejam mais apreciados do que os homens que redigem e instituem as leis, uma vez que esses trabalhos são realmente mais raros, mais difíceis de serem compostos, e necessitam de uma alma mais sensata, sobretudo, é claro, nos tempos hodiernos. (...) Pois bem, certamente eu sou mais verdadeiro e mais útil do que aqueles que pretendem incutir temperança e justiça nas pessoas. Pois eles as exortam a uma virtude e inteligência desconhecida pelos demais e somente debatida entre eles próprios, ao passo que eu, a uma virtude conhecida por todos.

A noção de tirania contida em seus discursos equivale à uma monarquia ruim $^{20}$, que não reconhece os direitos e liberdades (ISÓCRATES, Panegírico, 125-126), mais característica dos governantes bárbaros que dos gregos amantes da temperança (ISÓCRATES, Panegírico, 126-127). O tirano, como poderemos ver abaixo, não realiza uma distribuição meritocrática e equitativa das honrarias, concentrando o poder de forma desigual e, portanto, injusta. Ele exorta Filipe II da Macedônia a governar com justiça, pois mesmo nas

20 Os discursos de Isócrates apresentam visões conflitantes no que diz respeito ao tratamento da monarquia. Se no Panegírico a submissão ao poder autocrático é vista como algo que corrompe e afemina a alma, tornando-a "submissa e amedrontada" (151-153), no Filipe os gregos são incentivados a aceitar o domínio de Filipe II da Macedônia a fim de empreender guerras contra os bárbaros e finalmente atingir uma união pan-helênica. 
monarquias haveria perigo (ISÓCRATES, Filipe, 107-108): Dionísio I de Siracusa tornou-se um tirano ao extrapolar o poder que lhe era devido, sendo de baixo nascimento e menos inclinado à virtude (areté) (ISÓCRATES, Filipe, 65). Assim, Filipe II deveria estabelecer leis que assegurassem a liberdade dos gregos, sendo portador de virtude por sua origem aristocrática e sua educação helena (ISÓCRATES, Filipe, 67;127). Ele deveria compartilhar o exercício do poder com uma assembleia formada por aristocratas, tal como o regime espartano (Filipe, 80). A educação isocrática tornaria homens que já possuíam vocação para o bem ainda melhores, fazendo-os aptos para o desempenho de funções úteis e públicas para a pólis. Para Isócrates, a justiça (dikayosine) e a virtude (areté) não poderiam ser ensinadas, mas apenas aperfeiçoadas. Vejamos:

Digo-lhes que quem pretende ser proeminente seja nos discursos, nas ações, ou nas demais atividades, deve, antes de tudo, ser bem-dotado por natureza pra realizar aquilo para o qual foram designados; em seguida, ser educado e adquirir o conhecimento de cada assunto; por fim, dedicar-se e exercitar o uso e a experiência prática daquilo que foi aprendido. Sob essas condições, pois, alcança-se a perfeição em todas as atividades, destacado-se em muito dos demais (Antídose, 187, grifo nosso)

Assim como Platão, Isócrates não pensava no grande público quando elaborava suas obras. Sua audiência era quase sempre aristocrática (ISÓCRATES, Antídose, 69), e o conteúdo de seus discursos revela essa disposição a ver os bem-nascidos como aqueles que melhor conduziriam os rumos da pólis:

E nenhuma dessas coisas aconteceu sem razão, mas tudo terminou como esperado, pois é impossível que homens assim criados e governados partilhem de alguma virtude nem ergam um troféu sobre seus inimigos. Pois como se poderia produzir um estratego habilidoso ou um bom soldado em suas instituições, cuja maior parte é uma multidão desordenada e inexperiente dos perigos, imprestáveis para o combate e melhor educada para a escravidão do que os nossos escravos domésticos? (ISÓCRATES, Panegírico, 150, grifo nosso)

Uma definição clara de justiça para Isócrates é encontrada no Demônico. Nesse trecho é possível perceber que a ideia de dikayosine como "dar a cada um aquilo que lhe cabe". Ser justo é melhor que ser rico, e os maus, por quererem uma parcela maior do poder, quebram com a sophrosyne: 
Prepara-te para que possas obter vantagem, mas retém-te quando tiveres o mesmo que os outros, para que aparentes desejar a justiça não por causa de tua debilidade, mas por conta da tua equidade. Aceita antes a justa carência do que a riqueza injusta: a justiça é em tal escala melhor do que propriedades que, enquanto estas só ajudam enquanto se vive, aquela concede fama mesmo depois de morto, enquanto estas se encontram também entre os inferiores, aquela é impossível de ser obtida pelos perversos. Não imites ninguém que lucra com a injustiça, mas antes conforma-te com aqueles que recebem puniçóes como consequência de sua justiça: se os justos não têm nenhuma outra vantagem sobre os injustos, ao menos eles são detentores de expectativas muito maiores. (ISÓCRATES, Demônico, 38, grifos nossos)

Isocrates vê um governo dos "melhores" (aristoi) como verdadeira democracia, pois haveria o consentimento do demos que aqueles que receberam melhor educação devem estar à frente dos negócios da cidade (Aeropagítico, 11-30). Termos como basileia, monarkhia e tyrannia são usados sem muitas distinções em diversos discursos, tornando definições precisas sobre esses termos coisas difíceis de serem extraídas dos textos isocráticos (MORGAN, 2003, p. 183-184). É preciso reforçar que, para Isócrates, sem a participação dos letrados não é possível haver virtude ou justiça na cidade, pois esses dois elementos lhes seriam naturais.

É perceptível que mesmo com a inconsistência no uso dos termos listados, a tirania é sempre vista pelo retórico como um regime que suprime direitos dos aristoi. Como Platão, Aristófanes (OBER, 2005, p. 231) e outras figuras de destaque dos séculos V e IV a.C, Isocrates afirma que na democracia "radical" implantada por Péricles o demos age como tyrannos. Ele defende um retorno aos modelos elaborados por Sólon e Clístenes, nos quais a influência das elites no gerenciamento da pólis era evidente:

(...) Pois eu penso que a única maneira - a única maneira possível de evitar perigos futuros e nos livrar dos males do presente é que devemos estar dispostos a restaurarmos aquela primeira democracia que foi instituída por Sólon, que provou ser um amigo do povo acima de todos os outros, e que foi restabelecida por Clístenes, que derrubou os tiranos e trouxe o povo de volta ao poder - um governo que podemos não achar nenhum mais favorável à população ou mais vantajoso para toda a cidade. A maior prova disso é que aqueles que gozaram daquela constituição forjaram muitos atos nobres, ganharam a admiração de toda a humanidade, e tomaram seu lugar, com o consentimento comum de todos os helenos como a liderança da Hélade (...). (ISÓCRATES, Aeropagítico, 13-17, grifo nosso) 
Mas o que mais contribuiu para o seu (Sólon e Clístenes) bom governo da comunidade foi que das duas formas reconhecidas de equidade -aquela que dá a todos o mesmo e aquela que dá a cada homem o que lhe é adequado- eles (Sólon e Clístenes) não falharam em adotar a que era a mais benéfica. Mas, rejeitando como injusta aquela que coloca bons e maus como merecedores das mesmas honrarias, e preferindo ao invés aquela que recompensa e pune cada homem de acordo com seus méritos, eles (Sólon e Clístenes) governaram a cidade sob esse princípio, não ocupando as magistraturas pelo sorteio entre todos os cidadãos, mas selecionando os melhores e mais aptos para cada função da comunidade. (ISÓCRATES, Aeropagítico, 21-22, grifos nosso)

\section{Aristóteles $\ddagger$ A tirania e o exercício da virtude}

Logo no início deste texto apresentamos a visão aristotélica de bybris: um desrespeito à honra alheia pela posse de um excesso de orgulho pessoal. $\mathrm{O}$ bybristés retira do outro a parcela que lhe é devida na honra, cometendo uma injustiça, portanto. A oposição entre bybris e dikaiosyne no pensamento do estagirita fica ainda mais clara quando consideramos a Ética a Nicômaco: nesse texto a justiça é tratada como virtude moral e política (Livro II). Ela apresenta dois significados: o primeiro se relaciona à obediência das leis, àquilo que é o costume, tal como entende o senso comum; o segundo se refere à equidade, à justiça como virtude social, a ter aquilo que lhe cabe. $\mathrm{O}$ homem injusto é alguém que visa adquirir mais que sua devida porção das coisas:

Tomemos, pois, como ponto de partida os vários significados de "um homem injusto". Mas o homem sem lei, assim como o ganancioso e ímprobo, são considerados injustos, de forma que tanto o respeitador da lei como o honesto serão evidentemente justos. $\underline{\mathrm{O} \text { justo é, portanto, }}$ o respeitador da lei e o probo, e o injusto é o homem sem lei e ímprobo. Visto que o homem injusto é ganancioso, deve ter algo que ver com bens - não todos os bens, mas aqueles a que dizem respeito a prosperidade e a adversidade, e que tomados em absoluto são sempre bons, mas nem sempre o são para uma pessoa determinada. Ora, os homens almejam tais coisas e as buscam diligentemente; e isso é o contrário do que deveria ser. Deviam antes pedir aos deuses que as coisas que são boas em absoluto o fossem também para eles, e escolher essas. $\mathrm{O}$ homem injusto nem sempre escolhe o maior, mas também o menor no caso das coisas que são más em absoluto (ARISTÓTELES, Ética a Nicômaco, 1129a-b).

Baseando-nos no trecho acima citado, temos que analisar como o tirano se caracteriza no pensamento aristotélico: seria ele um homem justo ou injusto? A resposta não é muito difícil de ser dada uma vez que entramos 
em contato com a definição de tirania elaborada pelo filósofo. Aristóteles denomina esse regime como uma forma pervertida da monarquia, a mais distante do governo ideal -a politeia- que mistura democracia e oligarquia (ARISTÓTELES, Política, 1289a; 1293b), na qual apenas os interesses do governante são considerados e o poder é exercido "de forma despótica sobre a comunidade" (ARISTÓTELES, Política, 1279b). Aristóteles também vê semelhanças entre a democracia radical tal como fora construída por Péricles e as tiranias: nesses regimes predominariam a demagogia e a vontade da maioria, não havendo a justa distribuição das honrarias da pólis ou o devido respeito à lei, sendo contrários à politeia, o governo ideal para esse filósofo:

(...) Resulta daí que o Estado cai no domínio da multidão indigente e $\underline{\text { se vê subtraído ao império das leis. Os demagogos calcam-nas com os }}$ pés e fazem predominar os decretos. Tal gentalha é desconhecida nas democracias que a lei governa. Os melhores cidadãos têm ali o primeiro $\underline{\text { lugar. Mas onde as leis não têm força pululam os demagogos. O povo }}$ torna-se tirano. Trata-se de um ser composto de várias cabeças; elas dominam não cada uma separadamente, mas todas juntas. Não se sabe se é desta multidão ou do governo alternado e singular de vários de que fala Homero quando diz que "não é bom ter vários senhores". $\underline{\text { De }}$ qualquer modo, o povo, tendo sacudido o jugo da lei, quer governar só e se torna déspota. Seu governo não difere em nada da tirania. Os bajuladores são honrados, os homens de bem sujeitados. $\mathrm{O}$ mesmo arbítrio reina nos decretos do povo e nas ordens dos tiranos. Trata-se dos mesmos costumes. O que fazem os bajuladores de corte junto a estes, fazem os demagogos junto ao povo. Gozam do mesmo crédito. Sugerem-lhe o desprezo pelas leis, reduzem tudo à sua vontade, só respeitam os seus decretos, e depois de tê-lo tornado senhor de tudo, tendo suas opiniões e suas vontades entre as mãos, tornam-se seus senhores, por sua vez, pelo hábito que se contraiu de obedecer-lhes. Não se limitam aos assuntos gerais, atacam os magistrados em pessoa, atribuem ao povo o direito de julgá-los e, como este se presta de bom grado a sua instigação, terminam por dissolver tudo e tudo subverter. Não é sem razão que se censura tal governo e, de preferência, o chamam democracia ao invés de República (politeia); pois onde as leis não têm força não pode haver República (politeia), já que este regime não é senão uma maneira de ser do Estado em que as leis regulam todas as coisas em geral e os magistrados decidem sobre os casos particulares. (ARISTÓTELES, Política, 1291b-1292a)

A justiça em Aristóteles tem um caráter prático: ela deve ser aperfeiçoada nos hábitos cotidianos, pelo comedimento e rejeição dos excessos:

(...) nós nos tornamos justos ao realizar atos justos, temperados ao realizar atos equilibrados, bravos ao realizarmos atos corajosos. Essa 
verdade é atestada pela experiência das comunidades: os legisladores tornam os cidadãos em boas pessoas ao treina-los em hábitos de boas ações - esse é o objetivo de toda legislação, e se ela falha nisso ela é defeituosa. Isso é o que distingue uma boa constituição de uma ruim. (ARISTÓTELES, Ética a Nicômaco, 1103b, grifos nossos)

A eudaimonia (felicidade) seria, segundo o estagirita, inatingível nas tiranias, pois não é possível alcançar o bem comum, sendo o seu governo apenas preocupado com seus prórpios interesses (ARISTÓTELES, Ética a Nicômaco, 1097b-1098a; Política,1295a). O tirano fere a areté coletiva, uma vez que Aristóteles concebe a pólis como uma parceria de pessoas livres (Política, 1279a). Sob o comando do autocrata essa é apenas uma degradação do seu potencial para promover o bem-estar dos cidadãos (ARISTÓTELES, Política, 1295a; 1296a; 1311a; 1314a). Sendo a justiça uma virtude completa (ARISTÓTELES, Ética a Nicômaco, 1129b-1130a), o tirano não a possui, pois ser justo no pensamento aristotélico é agir não apenas para o próprio bem, mas para o de toda a comunidade, distribuindo equitativamente cargos, méritos e honrarias:

(...) é evidente que a ação justa é intermediária entre o agir injustamente e o ser vítima de injustiça; pois um deles é ter demais e o outro é ter demasiado pouco. A justiça é uma espécie de meio-termo, porém não no mesmo sentido que as outras virtudes, e sim porque se relaciona com uma quantia ou quantidade intermediária, enquanto a injustiça se relaciona com os extremos. E justiça é aquilo em virtude do qual se diz que o homem justo pratica, por escolha própria, o que é justo, e que distribui, seja entre si mesmo e um outro, seja entre dois outros, não de maneira a dar mais do que convém a si mesmo e menos ao próximo, mas de maneira a dar o que é igual de acordo com a proporção; e da mesma forma quando se trata de distribuir entre duas outras pessoas. (ARISTÓTELES, Ética a Nicômaco, 1133b-1134a)

Por isso o equitativo é justo, superior a uma espécie de justiça não à justiça absoluta, mas ao erro proveniente do caráter absoluto da disposição legal. E essa é a natureza do equitativo: uma correção da lei quando ela é deficiente em razão da sua universalidade. (ARISTÓTELES, Ética a Nicômaco, 1137b, grifos nossos)

O tirano seria, para Aristóteles, um bybristés porque atenta contra a virtude (areté) não apenas dos nobres, mas do corpo político como um todo. Ele é injusto e ganancioso, age com excesso, se desloca do caminho do meio, almeja mais que a sua parcela na timé (honra) pública. A tirania atentaria contra a própria natureza (ARISTÓTELES, Política, 1287b), impedindo a realização 
da virtude (areté) dos homens, ou seja, que cada um se desenvolva plenamente de acordo com a sua capacidade (ARISTÓTELES, Ética a Nicômaco, 1097b-1098a), e que contribua para a harmonia da pólis na medida de suas faculdades, o que fica evidente pela citação da parábola das espigas na Política (1284a; 1311a). O tirano não toma o caminho do meio e a comunidade sob seu governo não atinge seu telos (fim): proporcionar o alcance da eudaimonia para seus cidadãos.

\section{Conclusão}

$\mathrm{O}$ artigo procurou demonstrar as relações existentes entre bybris e justiça (themis/dike/dikaiosyne) na cultura política letrada ateniense do arcaísmo até o fim do período clássico. Foi possível perceber que ambas as noçóes se contrapunham já na poesia homérica, na qual a bybris heróica e suas consequências possuem caráter pedagógico para a audiência, ao mesmo tempo que delimita os limites humanos em oposição ao poder dos deuses. A justiça está associada, tanto em Homero quanto em Hesíodo àquilo que é posto pelo divino. Contudo, já no último é perceptível um deslocamento para o ambiente humano, e o questionamento das sentenças dadas pelos governantes. A ênfase na justiça como reguladora das relações entre pessoas pertencentes a uma mesma comunidade política é reforçada na poesia soloniana. Ela ainda retém um caráter divino, estando associada a um equilíbrio cósmico. Todavia, é importante salientar que já no século VI a.C a ideia de que a justiça seria alcançada pela elaboração de leis que regulassem a vida na pólis estava presente, sendo bastante visível nos escritos dos pensadores clássicos que abordamos neste trabalho. De themis divina, vemos as noções de diké e dikaiosyne ganharem força: a própria comunidade torna-se responsável por seus erros e acertos, por seu acesso ao que é justo.

O princípio da igualdade geométrica, distributiva e meritocrática permeou o pensamento letrado heleno -melhor dizer ateniense- durante todo o período arcaico e clássico. Aquiles se sente desonrado ao ser despojado do que via como sua justa parte pelo papel que desempenhava no cerco à Tróia: Briseida. Sólon afirma que não se desonrará ao tomar mais poder que o que lhe cabe, e nem ultrajará a comunidade ao reprimir os aristoi naquilo que entende ser o quinhão que lhes é devido nos negócios da cidade. Todavia, tal ideal de justiça não é o suficiente para o demos, não conseguindo equilibrar as relações entre esses e as elites. $\mathrm{O}$ tirano, assim, torna-se elemento catalisador das transformações desejadas pelas massas, ao mesmo tempo que retém a ideologia aristocrática que o gerou, a de ser "o melhor entre os melhores" 
(HOMERO, Ilíada, XI, 783-784). Contudo, ao minorar a participação dos kaloi kagathoi (bem-nascidos) na vida pública, o tirano ganhará a inimizade do grupo social a que pertence, o que se reflete nas fontes escritas que chegaram até nós, nas quais seu governo torna-se sinônimo de injustiça e desonra do corpo social, elemento presente nos escritos de Platão, Isócrates e Aristóteles, bem como de muitos outros autores clássicos. Assim, a recepção da literatura ateniense torna o tirano intrinsecamente ligado à noção de hybris. Tal conexão é evidenciada em episódios que retratam os tiranos como pessoas de moral degradada, amantes do luxo, da riqueza e dos prazeres carnais, descumpridores e não possuidores da diké que deve reger as relações sociais.

\title{
JUSTICE, HYBRIS AND TYRANNY IN ARCHAIC AND CLASSICAL ATHENS
}

\begin{abstract}
As stated by 4th century BC thinkers, especially Plato and Aristotle, tyranny was the worst form of government. However, the recent scholarship about autocracies in Ancient Greece has understood that the nexus between Athenians and tyranny was ambiguous. Hybris, in its turn, is a notion that underwent alterations during Ancient Greece's history. If in homeric and hesiodic poetry it was characterized as a behaviour contrary to righteousness (dike), a haughtiness marked by a demeanour at a level close to excess, during the Classical period the concept was mainly related to the attack against a citzen's honour (timé). In this article we intend to explore the connections between tyranny and bybris at Athens throughout Archaic (7th and 6 th centuries BC) and Classical (5th and 4th centuries BC) periods and understand the associations between tyrants and an undue, bybristic behavior during the mentioned time.

Keywords: Tyranny, Hybris, Athens
\end{abstract}

\section{Bibliografia}

\section{Documentação Textual}

ARCHILOCUS. Greek Iambic Poetry From the Seventh to the Fifth Centuries

BC. Tradução e edição de D.E. Gerber. Cambridge: Harvard University Press, 1999.

ARISTÓTELES. Constituição de Atenas. Trad. e comentários de Francisco Murari Pires. São Paulo: Editora Hucitec, 1995.

. Metafísica, Ética a Nicômaco, Poética. Trad. L. Vallandro e G.

Bornheim. São Paulo: Nova Cultural, 1987.

Política. Trad. Nestor S. Chaves. Bauru: Edipro, 2009.

. Retórica. Trad. Edson Bini. Bauru: Edipro, 2011.

ARISTOTLE. Aristotle in 23 Volumes. Trad. H. Tredennick. Cambridge: Harvard University Press, 1989. 
Press, 1990.

DEMOSTHENES. Demosthenes. Trad. N. W. DeWitt e N. J. DeWitt. Cambridge: Harvard University Press, 1949.

DIOGENES LAERTIUS. Lifes of Eminent Philosophers. Trad. R.D. Hicks. Cambridge: Harvard University Press, 1972.

HERODOTUS. The Persian Wars. Volumes I-IV.Trad. A.D. Godley. Cambridge:

Harvard University Press, 1920-1925.

HESÍODO. Os Trabalhos e os Dias. Trad. e Notas de L.O. Mantovaneli. São Paulo: Odysseus, 2011.

ISOCRATES. Speeches. 3 vol. Trad. G. Norlin. Cambridge: Harvard University Press, 1980.

ISÓCRATES. Panegírico. In: BERTACCHI, A.R. O Panegírico, de Isócrates: Tradução e Comentário. São Paulo: Usp, 2014. 151f. Tese (Doutorado em Letras Clássicas) - Departamento de Letras Clássicas e Vernáculas/Programa de PósGraduação em Letras Clássicas, 2014.

. Antídose. In: LACERDA, T. C. E. As Reflexões Metadiscursivas no Discurso Antídose de Isócrates. São Paulo: Usp, 2016. 280f. Tese (Doutorado em Letras Clássicas) - Departamento de Letras Clássicas e Vernáculas/Programa de PósGraduação em Letras Clássicas, 2016.

HOMÈRE. Iliade. Trad. P. Mazon. Paris: Les Belles Lettres, 1968.

HOMERO. Ilíada. Trad. Frederico Lourenço. Lisboa: Cotovia, 2014.

. Odisseia. Trad. Frederico Lourenço. Lisboa: Cotovia, 2008.

PLATÃO. República. Trad. E. Corvisieri. São Paulo: Nova Cultural, 1997.

Editores, 2000.

. Fedro ou Da Beleza. Trad. Pinharanda Gomes. Lisboa: Guimarães

PLATO. Plato in Twelve Volumes. Trad. P. Shorey, R.G Bury e W. Lamb. Cambridge, Harvard University Press, 1969.

SOLON. In: MAIA, C. A. M. O Individual e o Coletivo na Poesia de Sólon. Rio de Janeiro: UFRJ, 2008. 110f. Dissertação (Mestrado em Letras Clássicas) - Faculdade de Letras/Programa de Pós-Graduação em Letras Clássicas, 2008.

. In: LEWIS, J.D. Solon the Thinker: Political Thought in Archaic Athens. Londres: Duckworth, 2006.

THUCYDIDES. History of the Peloponesian War. 5 vol. Trad. C. F. Smith. Cambridge: Harvard University Press, 1965.

Referências

ANDERSON, G. 2005. Before Turannoi Were Tyrants: Rethinking a Chapter of Early Greek History. Classical Antiquity, Vol. 24, No. 2, p.173-222.

ANHALT, E. K. Solon the Singer: Politics and Poetics. Lanham: Rowman $\mathcal{E}$ Littlefield 1993.

BALOT, R.K. Greed and Injustice in Classical Athens. Princeton: Princeton University Press, 2001.

BLAISE, F. Poetics and Politics: Tradition Re-Woked in Solon's "Eunomia" (Poem 4). In: BLOK, J \& LARDINOIS, A.P.M.H. Solon of Athensः New Historical and Philological Approaches. Leiden: Brill, 2006.

BRYANT, J. M. Moral Codes and Social Structure in Ancient Greece: a Sociology of Greek Ethics from Homer to the Epicureans and Stoics. Nova Iorque: State University of New York Press, 1996. 
CAIRNS, D.L. Aidós: Psychology and the Ethics of Honour and Shame in Ancient Greek Literature. Oxford: Claredon Press, 1994 . Hybris, Dishonour, and Thinking Big. The Journal of Hellenic Studies,

Vol. 116, 1996, p. 1-32.

CEFAÏ, D. \& LICHTERMAN, P. The Idea of Political Culture. In: GOODIN, R.E. \& TILLY, C. (eds.) The Oxford Handbook of Contextual Political Analysis. Oxford: Oxford University Press, 2006.

CONDILO, C.S. Heródoto, as tiranias e o pensamento político nas Histórias. São Paulo: Annablume, 2010.

CONNOR, W.R. 'Tyrannis Polis'. In: D'ARMS, J. H. \& EADIE, J.W. Ancient and

Modernः Essays in Honor of Gerald F. Else. Ann Arbor: University of Michigan, 1977.

DETIENNE, M. Os mestres da verdade na Grécia Arcaica. São Paulo: Martins Fontes, 2013.

DEWALD, C. Form and content: the question of tyranny in Herodotus. In: MORGAN, K. A. (org.). Popular Tyranny. Austin: University of Texas Press, 2003.

DICKIE, M.W. "Hesychia and Hybris in Pindar" In: GERBER, D.E. Greek poetry and philosophy: studies in honour of Leonard Woodbury. Chico: Scholars Press, 1984.

DUPLOY, A.; MARIAUD, O. \& POLIGNAC, F. Sociétés Grecques du VII Siècle. In: ÉTIENNE, Roland. La Méditerranée au VII Siècle av* J+-C.* Essais d'Analyses Archéologiques. Paris: De Boccard, 2010.

FINLEY, M.I. Política no Mundo Antigo. Lisboa: Edições 70, 1997.

FISHER, N.R.E. “The law of hubris in Athens" In: CARTLEDGE, P.; MILLET, P. \& TODD, S. Nomos: Essays in Athenian Law, Politics and Society. Cambridge: Cambridge University Press, 1990.

. Hybris a study in the values of honour and shame in Ancient Greece. Warminster: Aris and Phillips, 1992.

FOUCALT, M. História da Sexualidade 2: o Uso dos Prazeres. Rio de Janeiro: Graal, 1998 .

GERNET, L. Recherches sur le Développement de la Pensée Juridique en Grèce Ancienne. Paris: Albin Michel, 2001.

HARTOG, F. O espelho de Heródoto: ensaio sobre a representação do outro. Belo Horizonte: UFMG, 1999.

IRWIN, E. Solon and Early Greek Poetry: The Politics of Exhortation. Cambridge: Cambridge University Press, 2005.

JAEGER, W. Paideia: a formação do homem grego. São Paulo: Martins Fontes, 2013.

KALlET, L. Demos Tyrannos: Wealth, Power and Economic Patronage. In: MORGAN, K. (ed.) Popular Tyranny. Austin: University of Texas Press, 2003.

LAFER, M.C.N. Prometeu e Pandora. In: HESÍODO. Os Trabalhos e os Dias. Trad. e notas de M.C.N. Lafer. São Paulo: Iluminuras, 1996.

LEFÈVRE, F. História do Mundo Grego Antigo. São Paulo: Martins Fontes, 2013.

LEWIS, S. Greek Tyranny* Exeter: Bristol Phoenix Press, 2009.

MANTOVANELI, L.O. Apresentação. In: HESÍODO. Os Trabalhos e os Dias.

Trad. e Notas de L.O. Mantovaneli. São Paulo: Odysseus, 2011. 
MCGLEW, J.F. Tyranny and Political Culture in Ancient Greece. Ithaca: Cornell University Press, 1993.

MORGAN, K. A. The Tyranny of the Audience in Plato and Isocrates. In: MORGAN, K. A. (org.). Popular Tyranny. Austin: University of Texas Press, 2003.

MOSSÈ, C. A Grécia Arcaica de Homero a Ésquilo. Lisboa: Edições 70, 1989.

MUNN, M. The Mother of the Gods, Athens and the Tyranny of Asia: a Study of Sovereignty in Ancient Religion. Berkeley: University of California Press, 2006.

MURRAY, O. The Solonian law of bubris. In: CARTLEDGE, P; MILLET, P. $\&$ TODD, S. Nomos: Essays in Athenian Law, Politics and Society. Cambridge: Cambridge University Press, 1990.

OBER, J. Athenian Legacies: Essays on the Politics of Going On Together. Princeton: Princeton University Press, 2005.

PARKER, V. Túrannos: The Semantics of a Political Concept from Archilochus to Aristotle. Hermes, no 126, 1998, p.145-72.

RAAFLAUB, K. "Stick and Glue": The Function of Tyranny in Fifth-Century Athenian Democracy. In: MORGAN, K.A. Popular Tyranny. Austin: University of Texas Press, 2003.

ROBERTSON, H.G. The Hybristes in Homer, The Classical Journal, 1955, vol. $51, \mathrm{n}^{\circ} 2, \mathrm{p} .81-83$.

SULLIVAN, S. D. Psychological and Ethical Ideas: What Eearly Greeks Say* Leiden: Brill, 1995.

THEML, N. O Público e o Privado na Grécia do VIII ao IV a. C.: o Modelo Ateniense. Rio de Janeiro: Sette Letras, 1998.

TRALBUSI, J. A. D. TRALBUSI, J.A. D. Ensaio Sobre a Mobilização Política na Grécia Antiga. Belo Horizonte: UFMG, 2001.

. Dionisismo, Poder e Sociedade. Belo Horizonte: UFMG, 2004.

VERNANT, J-P. Mito e Pensamento Entre os Gregos. São Paulo: Paz e Terra, 1983.

. Mito e sociedade na Grécia Antiga. Rio de Janeiro: José Olympio, 1999.

. As Origens do Pensamento Grego. Rio de Janeiro: Difel, 2009.

VIRGOLINO, M.F. Tirania Cipsélida e a Promoção de Cultos Populares em Corinto Arcaica. Alethéia (Goiânia), 2014, v. 9, n. 2, p. 126-135.

- "Seja Previdente com Tudo": Periandros de Corinto, Tirania

e Sabedoria na Grécia Antiga. In: SEMINÁRIO FLUMINENSE DE PÓSGRADUANDOS EM HISTÓRIA, 4, 2016, São Gonçalo. Anais do IV Seminário Fluminense de Pós-graduandos em História. Rio de Janeiro: Anpuh-Rio, 2016, 2367 p. Disponível em: http://site.anpuh.org/index.php/encontros-regionais/seminariofluminense-de-pos-graduandos-em-historia/item/3972-anais

WEST, M. L. Iambi et Elegi Graeci ante Alexandrum Cantati. Oxford: Oxford University Press, 1998.

WILL, Édouard. Korinthiaka: Recherches sur 1'Histoire de la Civilization de Corinthe des Origines aux Guerres Médiques. Paris: E. de Boccard, 1955. 